\title{
Youth Categories and Drugs in Kosovo (2001-2014)
}

\author{
MSc. Rrahman Sylejmani, PhD Cand. \\ Colonel in Kosovo Police \\ rrahmansylejmani@gmail.com
}

\begin{abstract}
The use of narcotic substances has become a phenomenon of great concern, not only in Kosovo but also in all other countries of the world. Although in Kosovo there are no accurate statistics on how many individuals are regular users of narcotic substances, it is calculated that there are approximately 20.000 users. To add to this concerning issue, is the fact that the usage of narcotics in elementary and secondary school pupils and students. The objective of this paper is to offer a more realistic presentation of the cases of narcotic users from the new age groups. The goal is to identify the factors that influence the increase of this phenomenon, which is increasing specifically among the youth and is dangerous for public health and the public order and safety. The Kosovo Institutions have approved a National Strategy and action plan for Fighting the Use of Narcotic that is now being implemented. According to the Kosovo Police this strategy has had some positive results. Kosovo Police held more than 150 operations a year in all Kosovo, with a goal of issuing prosecutorial charges against suspected individuals that are active in different individual and group forms, regarding the cultivation and trafficking of drugs. According to the statistics from the Kosovo Police, during the 2012 there was a significant increase of confiscated narcotic substances in comparison with 2011, the percentage of the confiscation of Marihuana has increased around $400 \%$. The use of narcotics among young people is considered as a growing phenomenon. I consider that this is primarily a result of the lack of awareness among the youth regarding the potential dangers for health and social aspects, and lack of specialized institutions for treatment and rehabilitation of the addicted individuals. Lack of appropriate institutional treatment of this phenomenon represents a danger not only for public health but for the safety and public order in general.
\end{abstract}

Keywords: Narcotic substances, police, institutional, youth.

\section{The use of narcotics in Kosovo}

Kosovo had no precise official statistics on drug users, but after the last war in Kosovo in 1998 -1999, in 2001 the authorities began with the recording of the data and it is considered that by 2014 there are approximately 20,000 individuals as drug users. (Available for download at http://www. telegrafi. com/lajme/kosova-me-20-mije-perdorues-droge-2-42830. html. )

The fact that remains is a concern of the use of narcotic substances in primary and secondary schools in Kosovo. For example, just in the course of 2014 there were 190 marijuana users, 11 users of heroin and 22 cocaine users (these addicts said they are regular users of these substances and that they also used other substances. ) (Kosovo Police, the Directorate for Investigation drug trafficking, Annual Report 2014. )

Although precise data is non-existent in the central level to cover the whole territory of Kosovo, it is worth noting that, according to the director of Therapeutic-Rehabilitation Center "Labirynth" there are more drug users in schools (http://www. labirinti-ks. org) where young people begin to use drugs between the ages of 12-16 years.

In total there are 12 registered cases that have to do with schools, with a total of 15 arrests and confiscated 217.67 grams of marijuana. 
According to the director of the Center for Rehabilitation "Labyrinth" during 2001, the average age of drug users has been 24 years old. But disturbing fact is that during 2014 it was noted that the age has dropped from 24 year olds in the group between 12-15 years of age. This means that the use of drugs, in addition to the increased phenomenon also began to include younger category of people. According to the Director of the NGO "Labyrinth:" -"[T]he average age of initiation into drug use has decreased over the years. The average age in the beginning of the year 2006 was 19. 2, while in 2013 it was 16. 7. There have been cases when a young person who started the abuse of drugs was 12 years old. (For more, read at: (http://www. labirinti-ks. org)

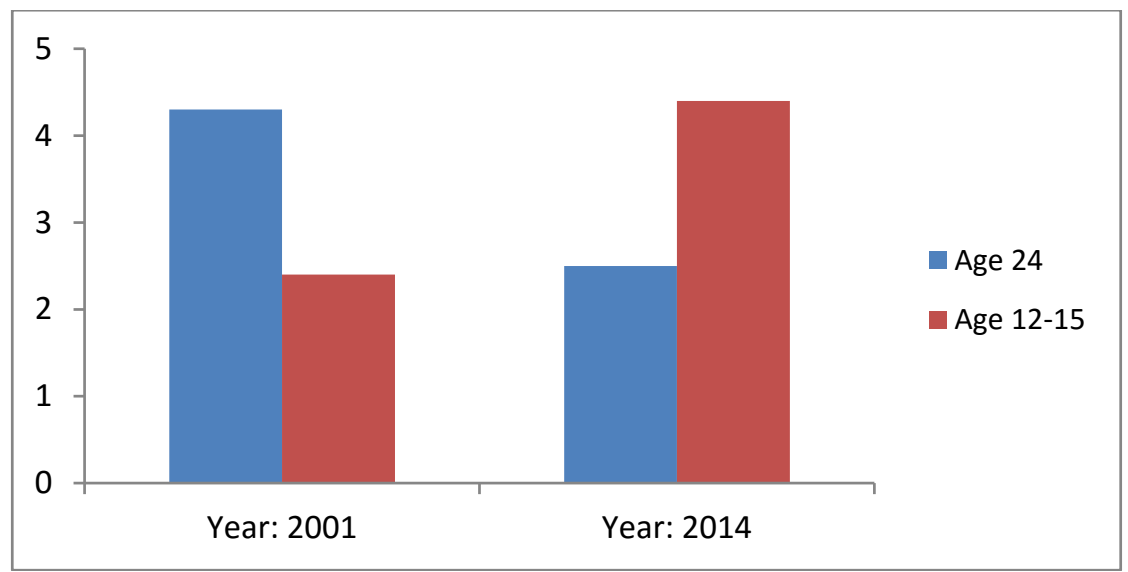

Graph No. 1: age groups of drug users (Source: Statistics taken from: http://www. labirinti-ks. org/

Due to the fact that drug use started to become a phenomenon with ages of 16 , this is becoming very troublesome and if more stringent measures institutional are not taken, it will actually lead to danger and risk for age group under 16 years.

One should have in mind that adolescence, which is a very turbulent phase because at this stage of the development young people are overwhelmed with new feelings, they are in search for their dreams and face changes, "child entering the teenage time in many families often arises drastic changes" (Cop-Blažič N., 2003: 21). Therefore, without their corresponding guidelines they can get lost in the wrong way, which can also include the use of narcotics.

\section{From this study it was noted that not only men are drug users.}

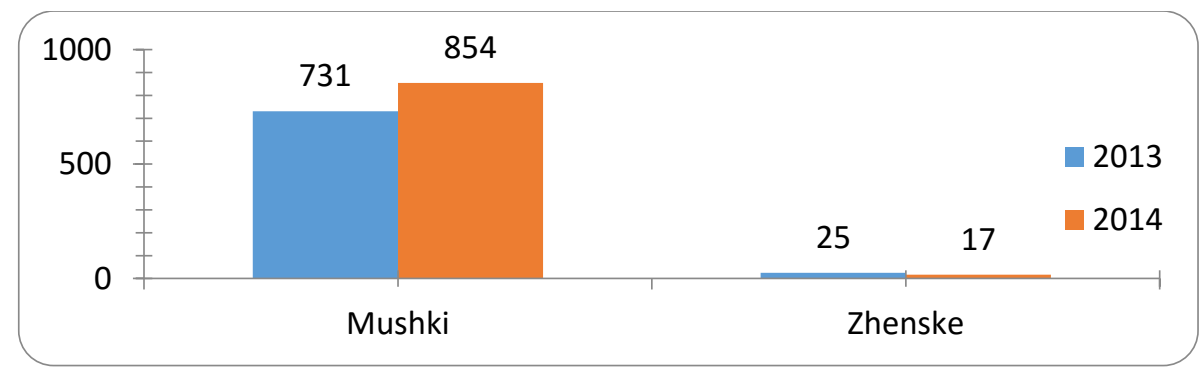

Graph no 2: gender representation of drug users. Source: Kosovo Police, Directorate for Investigation of Drug Trafficking, the Annual Report for 2014 no. ISC-06 / 2-02 / 014/2015

Although a very small number, according to the Kosovo Police, in the above-indicated graph no. 2, it can be seen that also women are drug users. For example in 2013 of 731 men 25 users are female. Also in 2014, the number of female drug users is very small, where they registered 17 cases. 


\section{Drug use in primary and secondary schools}

It is evident that among drug users are pupils/students in the primary and secondary schools in Kosovo. Although in respect of this phenomenon there are no comprehensive and accurate data, while the Minister of Education of Kosovo, in 2013 report to the Assembly of Kosovo, on the issue of drug use in schools said that: "20\% of high school students use different types of drugs and there was a drop in age of beginning of drug use that affects the age of 12-13 years, particularly the 8th grade of primary school, and that the drug is distributed in most bars around close proximity to primary and secondary schools in Kosovo. (http://www. kuvendikosoves. org /? cid = 1,128,5618.)

The Police stated that 12 registered cases related to schools and their sorroundings. A total of 15 persons were arrested and 217. $67 \mathrm{gr}$. marijuana was confiscated, while one case was NN (name uknown). For these cases, school authorities have informed the police but that were received various other information by other sources. (Kosovo Police, Annual Report 2014, the Directorate for Investigation of Drug Trafficking).

\section{The causes of such a situation}

If you look at the statistics of age groups of drug users, drug use is associated with a weakening of the nucleus of large families in Kosovo. In 2001, when there were fewer drug users and that age group were not young, that was the age when large families were still present, or rather just as first step of wakening and reduction the large families began to show up.

Weakening role of the extended family and the emergence of smaller close family consisting of only parents and children, or children with one parent, influenced the emergence of disobedience of children against their parents. Normally, there is a diffrence between childrearing in an extended family with a traditional core, which in addition to parents lived with grandparents, uncles and others, while it is quite different and harder to come up with child raring only by both parents.

School as one of the most important institutions for the socialization and education of young people, which plays a key factor in the education of students at the same time it has become the nest where students learn the first steps of drug use.

As another reason for drug use in schools we consider to be the lack of psychologists and sociologists. Although this year, for example, the Municipality of Prishtina employed 10 psychologists in schools, which is not enough, because sociologists and phsychologists were missing in most of the schools, who are qualified to monitor and treat behavior of students with the sociological and psychological aspects.

Lack of awareness among children about caring for their health, as mentioned above greatly affects all children, especially children who are drug users "[D]rug users are always in front of one unknown and you do not know exactly how their bodies will react after each used doses. " (Nora M., L. Sokol, 2012: 196. )

It should be noted that in Kosovo there is no center at the state level for rehabilitation and recovery from addiction and drug abuse. In this situation, drug addicts even when they would like to turn for help have no where to turn, especially to the authorities that are supposed to help all addicts. The only authority that has been helping and meeting the demands of this category is the NGO "Labyrinth."

\section{The use of narcotics in Albania}

In the beginning it is very important to note that last time in Albania an inciative emerged in Parliament and civil society to legalize the use of light drugs such as marijuana, which is grown in the south. Until now, such inciative was not met with approval and support by institutions and civil society.

According to the UN report, which refers to a study in 2011 on drugs and crime situation in Albania, it is stated that 'are about 65,000 drug users in Albania: Available at: (http://shqiptarja. com/home/1/raporti- per-drugs-65-me-Përdoruesiheroine-not-shqiperi-125038. html. )

In Albania, according to the chief of department of toxicology in Tirana - prof. dr. Zihni Sulaj: not only men are drug users, but also girls and women make up $10 \%$. Besides, what is even more alarming according to the toxicology service, that 
couples with children have created an addiction to drugs. (Related article available at: http://fax. al/read/news/717214/9918411/rritet-perdorimi-i-droges-nga-femrat-mjeket-perbejne-10-te-perdoruesve. )

Given the fact that Albania and Kosovo are different in terms of population since Albania now has about 1 million more inhabitants and it is considered that there are many more drug users than in Kosovo, speaking in numbers around 45,000 users more than in Kosovo. For example, according to the Institute of Statistics of Albania (INSTAT) - in January 2015, there were 2,893,005 registered residents (http://www. instat. gov. al. ) While the population in Kosovo, according to the Statistics Agency of Kosovo, is 1,739,825, without the north of Kosovo. (http://ask. rks-gov. net. )

Another element that distinguishes this country from Kosovo is that we have more drug users among women than men. According to the European Monitoring Centre for Drugs in Albania (EMCD) percentage of women drug users varies from 10-15\%, (http://www. emcdda. europa. eu. ) In Kosovo, according to research EMCD implemented in Kosovo, it is stated that women in the total number of drug users account for 2. $2 \%$. Available at: (http://www. emcdda. europa. eu/html. cfm/index211587SQ. html\#gps).

In Albania there are no exact data, but estimates show that drug users are mainly from the younger categories. Every year, the level of drug use by young people is increasing. Number of drug users indicates a growing trend, but what remains problematic is that these users are of teenage years, so that about $6-7 \%$ of young people use drugs. This assertion is supported by the study that was conducted among young people in schools aged 14-18, by the Institute of Public Health in collaboration with other national and international bodies, found that $5.4 \%$ of respondents had experimented with using canabis. Available at: (http://ishp. gov. al)

\section{Legal mechanisms and strategic documents}

Kosovo as a new country, has aligned its legislative basis with all the regulations of the European Union as well as with International Conventions of the United Nations.

The Assembly of Kosovo in 2008, adopted the Law on Narcotic Drugs, Psychotropic Substances and Precursors (Official Gazette, Law No. 02 / L-128. ) This law states that "[T]he use, possession, production and trafficking of narcotic drugs, is considered a criminal offense under the criminal code."

Criminal Code of Kosovo, no. 04 / L-82/2012 regarding the drug provided in XXIII chapter for crimes related to narcotics in Articles 273-282, criminal offenses, including the purchase, possession, distribution and sale of unauthorized drugs, illicit production and processing, unauthorized posession, intoxication of others, to facilitate the obtaining of drugs, narcotic plant breeding, organizing, directing or financing of drug trafficking, the conversion or transfer of property acquired by completion of these offenses, the punishment for severe cases and reimbursement of costs for law enforcement agencies.

Any person arrested by the police for possession, use, manufacture and trafficking of drugs is considered as a suspect for a crime or lawbreaker addicts. Such persons are entered in the records database of the Kosovo Police (Kosovo Police Information System KPIS), which records the number of cases and the authors responsible for each type of injury.

The new Criminal Code and new Criminal Procedure Code entered into force in January 2013. The legislator is in a separate chapter predevidio new provisions on how to deal with crimes related to drugs. For possession of less than 3 grams for the first time can be given a fine or imprisonment up to one year. In difficult circumstances (such as crimes involving distribution and trafficking) the punishment may be increased to 12 years. Production of the drug can be punished with a fine and imprisonment of six months to 10 years. In the case of large quantities of drugs, then the penalty can be increased to 15 years. A person involved in the activities of organized crime including drug, can be fined up to 250,000 euros and imprisonment of at least seven years, and in aggravating circumstances, those who organize, the penalty can be increased to 500,000 and at least 10 years in prison.

Law on Public Health no. 02 / L-078

Law on medicinal products and medical devices, no. 2003/26. 
The Kosovo government recently adopted several strategic documents for the period of time 2012-2017, in the context of drugs, Combating organized crime and managing the integrated state border/IBM.

The Strategy on HIVIAIDS and mental health are those negative aspects of drug use. The strategy for mental health services in Kosovo for the period 2008-2013, for example, says it will develop mental health services by 2013 , its institutions/facilities for treating drug addiction.

Through the new strategic documents, the government with its law enforcement agencies aim to reduce drug use through various forms of prevention and efficiency of the authorized service to detect and combat all forms of organized crime, including drugs.

Memorandum of Understanding between the Kosovo police and the NGO "Labyrinth" is regulated the strengthening of cooperation and coordination of activities related to the prevention and fight against human trafficking and drug abuse. This memorandum provided as ways of efficiently as possible to implement the action plan of the national strategy against drugs as well as the coordination of activities between the Department on Drugs and the NGO "Labyrinth."

What we see every day in the local media that there are various barriers to the realization of the mentioned projects, which are related to the lack of financial support. Also, we can not find any specific report which will assess and monitor the use of intoxicating substances, which will indicate the level of treatment of drug addicts.

\section{Conclusions and recommendations to improve the situation}

As stated above, we believe that awareness among youth categories such as students is not in satisfactory level, in terms of identification and impact of drugs in damaging their health, although some activities by the Kosovo Police, as well as other relevant institutions and organizations, but even these activities for the drugs do not have a permanent character but are confined only to certain dates and periods, and it's not enough.

It is necessary to do more especially in the design of specific programs in the media by showing on confidential way through special TV shows consequences of drug use and socio-psychological consequences that may result by the use of these substances. This element of awareness raising is necessary to be realized in every place where drug use is done by the youth categories and in need of greater addressed in order to preserve their health. Raising awareness for the protection of health for these categories of students is a prerequisite and a contribution to reducing the use of drugs in schools.

In Kosovo, there is no special institution, a centre on the state level for the rehabilitation and recovery of addicts. Drug users have no where to turn to state institutions for treatment or help. Kosovo urgently needs to establish such a center because it will surely contribute directly to preventing and reducing the incidence of this phenomenon.

Legal mechanisms and strategies are rare but it's another question how efficient they are, how much, and how they are implemented in practice. Although Kosovo police, in the context of these strategy, has taken some steps in order to efficiently prevent this phenomenon, which still remains as a problem for all categories of the population and especially for the younger age groups. The Kosovo government needs to constantly, through specific bodies, monitor the implementation of these strategies, which as for now in Kosovo is not satisfactory, which is especially shown in the non-fulfillment of their main goals in the prevention of such phenomena.

In a country that still bears the consequences of transition as is the case with Albania, which is the country of origin for marijuana, its institutions do good that the proposals for narcotic drug legalization do not met with approval, because it still should not be legalized, because legalization would contribute only to increase of the number of users as well as the smuggling would become even more pronounced than before.

I also believe that Kosovo should not initiate such inciative for legalization for the use and sale of drugs, but all efforts should be directed on greater prevention and also, in terms of social rehabilitation, in particular on treatment and healing of the existing number of addicts through the establishment of specialized institutions to be monitored and financed by the government. Now it is almost all of this a burden of an NGO that is not able to even have the possibility for themselves to cope with the whole of this problem. 


\section{Literature}

Literature from the books:

Cop-Blazic Nevenka, Put u život bez ovisnosti o drogama, 'Genesis', Zagreb, 2003.

Kosovska Policija, Direkcija za istragu trgovine narkoticima, Godišnji Izveštaj 2014 godine.

Krivični Zakon Kosova br. 04/L-082 od 20. aprilla 2012 god.

Malaj Nora, Sokoli Lekë: Savremeni socialni problem, 'Morava', 2012.

Sokoli Lekë, Droga, ISPS\&Rinia, 2001”.

Zakon o Krivičnom Postupku Kosova br. 04/ L-123 od 13. decembar 2012. god.

Internet sites used:

http://kosovopolice. com/?page=1,26,1985

http://www. telegrafi. com/lajme/kosova-me-20-mije-perdorues-droge-2-42830. html

http://www. labirinti-ks. org/

http://www. kuvendikosoves. org/?cid=1,128,5618

http://shqiptarja. com/home/1/raporti-per-drogen-65-mije-perdorues-heroine-ne-shqiperi-125038. htmlhttp://shqiptarja. com/home/1/raporti-per-drogen-65-mije-perdorues-heroine-ne-shqiperi-125038. html

http://www. instat. gov. al/al//rreth-nesh. aspx

http://fax. al/read/news/717214/9918411/rritet-perdorimi-i-droges-nga-femrat-mjeket-perbejne-10-te-perdoruesve

http://ask. rks-gov. net

http://ishp. gov. al/ 